\title{
Hubungan Faktor Risiko dan Karakteristik Gejala Klinis dengan Kejadian Pneumonia pada Balita
}

\author{
Lisa Adhia Garina, ${ }^{1}$ Sherly Fajariani Putri, ${ }^{2}$ Yuniarti ${ }^{3}$ \\ ${ }^{1}$ Bagian Ilmu Kesehatan Anak FK Unisba, ${ }^{2}$ Dokter Internship RSUD Sumedang, \\ ${ }^{3}$ Bagian Anatomi FK Unisba
}

\begin{abstract}
Abstrak
Pneumonia masih merupakan penyebab kesakitan dan kematian pada balita di negara berkembang. Faktor risiko pneumonia yang selalu ada (definite risk factor) meliputi gizi kurang, bayi berat lahir rendah (BBLR), tidak memberikan ASI, polusi udara di dalam ruang, dan pemukiman padat. Gejala pneumonia bervariasi bergantung pada usia penderita dan penyebab infeksinya. Tujuan penelitian ini menilai hubungan faktor risiko dan karakteristik gejala klinis dengan kejadian pneumonia pada balita. Penelitian cross sectional dilaksanakan di UPT Puskesmas Ibrahim Aji Kota Bandung periode April-Juni 2012 pada anak balita usia 6 bulan sampai dengan 59 bulan dengan diagnosis pneumonia dan bukan pneumonia berdasarkan kriteria WHO. Data demografis, faktor risiko, dan karakteristik gejala klinis dicatat dalam formulir penelitian. Penderita pneumonia pada balita terbanyak berusia 6-24 bulan (72\%), berjenis kelamin laki-laki (63\%), status gizi kurang (56\%) berdasarkan BB/U, tidak BBLR (95\%), diberikan ASI eksklusif(91\%), dan imunisasi dasar lengkap (93\%). Analisis uji hubungan antara kejadian pneumonia dan status gizi kurang berdasarkan BB/U didapatkan hasil $\mathrm{p}<0,001 ; \mathrm{r}=-0,7$ dengan lama demam $(\mathrm{p}=0,024$; $\mathrm{r}=-0,2)$, lama batuk $(\mathrm{p}=0,048 ; \mathrm{r}=-0,2)$, dan takipnea $(\mathrm{p}<0,001 ; \mathrm{r}=-0,8)$. Simpulan, terdapat hubungan status gizi kurang, lama demam, lama batuk, dan takipnea dengan kejadian pneumonia pada balita.
\end{abstract}

Kata kunci: Faktor risiko, gejala klinis, pneumonia, status gizi

\section{Correlation of Risk Factors and Clinical Characteristics with the Incidence of Pneumonia in Children under Five Years}

\begin{abstract}
Pneumonia is the leading infectious cause of death in children mostly in developing countries. Risk factors on pneumonia include malnutrition, low birth weight, non breastfeeding, air room pollution, and densely populated area. Symptoms of pneumonia vary depending on the age of the patient and cause infection. The purpose of this study was to assess the relationship risk factor and characteristic clinical symptoms with pneumonia. Cross-sectional study in Primary Health Care Ibrahim Aji Bandung during April-June 2012 among children aged 6 months to 59 months with a diagnosis of pneumonia and not pneumonia based on WHO criteria. Data on demographic, risk factor, and characteristics clinical symptoms were recorded. Pneumonia mostly attacking age 6-24 months (72\%), male (63\%), malnutrition status (56\%) based on the weight/age, non low birth weight (95\%), exclusive breastfeeding (91\%), and immunization (93\%). The association between the incidence of pneumonia with poor nutritional status ( $\mathrm{p}<0.001, \mathrm{r}=-0.7)$, duration of fever $(\mathrm{p}=0.024, \mathrm{r}=-0.2)$, duration of coughing $(\mathrm{p}=0.048, \mathrm{r}=-0.2)$ and tachypnoea $(\mathrm{p}<0.001, \mathrm{r}=-0.8)$. In conclusion, there is a relationship between poor nutritional status, duration of fever, duration of coughing, and tachypnoea with pneumonia.
\end{abstract}

Key words: Clinical symptoms, nutritional status, pneumonia, risk factor 


\section{Pendahuluan}

Penyakit pneumonia merupakan suatu penyakit berupa inflamasi yang terjadi pada parenkim paru. Penyakit ini merupakan infeksi saluran pernapasan yang pada sebagian besar disebabkan oleh mikroorganisme, yaitu virus danjugabakteri. ${ }^{1}$ Pneumonia merupakan salah satu penyebab kematian paling tinggi pada anak usia di bawah lima tahun bila dibandingkan dengan penyakit lainnya di dunia, diperkirakan 9 juta kematian anak terjadi pada tahun 2007 sekitar 20\% atau 1,8 juta kematian disebabkan oleh pneumonia. ${ }^{2,3}$

Kematian balita oleh karena pneumonia di seluruh dunia sebanyak 1,6-2,2 juta kematian setiap tahunnya dan sebagian besar terjadi di negara yang berkembang, 70\% terdapat di Afrika dan juga Asia Tenggara. ${ }^{4}$ Indonesia menempati urutan keenam negara dengan kasus pneumonia yang terbanyak. ${ }^{5}$ Berdasarkan atas data Riset Kesehatan Dasar (Riskedas) pada tahun 2013, insidensi dan juga prevalensi pneumonia adalah sebesar 1,8\% dan 4,5\%. ${ }^{6}$ Berdasarkan data yang didapat dari Dinas Kesehatan, ternyata proporsi pneumonia pada balita sebesar 22,18\% dengan kasus yang ditemukan sebanyak 390.319 kasus. $^{7}$

Faktor-faktor risiko yang selalu ada (definite risk factors) pada pneumonia balita adalah gizi kurang, bayi berat lahir rendah, tidak memberikan air susu ibu (ASI), polusi udara di dalam ruangan, dan pemukiman yang padat. Faktor risiko ini memerlukan intervensi supaya penurunan angka insidensi pneumonia akan berdampak signifikan pada penurunan angka kematian anak balita. ${ }^{4}$ Asupan gizi yang kurang merupakan salah satu faktor risiko untuk kejadian dan kematian balita disebabkan oleh infeksi saluran pernapasan. ${ }^{8}$

Gejala pneumonia bervariasi bergantung pada penyebab infeksinya, kelompok usia anak, dan berat ringan infeksi. Pneumonia disebabkan oleh bakteri biasanya mengakibatkan anak sakit berat yang mendadak dengan demam tinggi dan napas cepat. Gejala yang sering ditemui pada anak pneumonia adalah laju napas yang cepat, kesulitan bernapas, batuk, demam, menggigil, sakit kepala, nafsu makan yang menurun, dan juga terdengar ronki pada pemeriksaan fisis. ${ }^{1,8}$ Diagnosis pneumonia dipastikan dengan foto rontgen dada ( $x$-ray) dan juga uji laboratorium, tetapi di tempat dengan fasilitas yang terbatas, kasus dugaan terjadi pneumonia dapat ditetapkan secara klinis. Pedoman untuk temuan kasuskasus pneumonia itu menurut Badan Kesehatan
Dunia atau World Health Organization dapat ditetapkan dengan cara yang sederhana dan mudah sehingga pemberi pelayanan akan dapat menentukan secara dini gejala pneumonia dan dapat memberikan pengobatannya secara tepat. ${ }^{8}$ Program pemberantasan penyakit infeksi pada saluran pernapasan atas (ISPA) dalam rangka upaya untuk meningkatkan cakupan penemuan pneumonia pada anak balita, yaitu dengan cara pendekatan manajemen terpadu balita sakit atau MTBS. Manajemen terpadu balita yang sakit merupakan suatu program yang diperkenalkan oleh World Health Organization atau WHO, yaitu standar pelayanan dan tatalaksana pada anak balita yang sakit secara terpadu di fasilitas kesehatan tingkat dasar yang dapat menjelaskan tentang penilaian, klasifikasinya hingga tindakan untuk pengobatan selanjutnya, dengan tujuan menurunkan angka kematian serta kesakitan bayi dan anak balita di negara-negara berkembang. ${ }^{9}$ Tujuan penelitian adalah menilai hubungan faktor risiko dan juga karakteristik gejala klinis dengan kejadian pneumonia pada balita.

\section{Metode}

Penelitian dengan menggunakan desain cross sectional dilakukan di UPT Puskesmas Ibrahim Aji mulai bulan April sampai dengan Juni 2012. Populasi penelitian adalah anak balita usia 6-59 bulan yang datang berobat ke klinik rawat jalan dan atau pasien yang dirawat dengan diagnosis pneumonia dan bukan pneumonia sesuai kriteria WHO, berupa demam dan batuk dapat disertai pilek tanpa disertai napas cepat atau demam dan batuk disertai napas cepat sesuai usia dan/ atau sesak napas (ditandai retraksi sela iga, suprasternal, subkosta dan epigastrium, napas cuping hidung, serta sianosis). Kriteria eksklusi adalah anak balita dengan diagnosis pneumonia yang disertai penyakit lainnya seperti HIV-AIDS, penyakit jantung bawaan, dan tuberkulosis.

Teknik pengambilan sampel pada penelitian ini dengan menggunkan metode simple random sampling. Besarnya sampel pada penelitian ini ditentukan berdasarkan rumus uji hipotesis dua proporsi, besar sampel minimal untuk penelitian ini adalah 43 orang untuk balita dengan diagnosis pneumonia dan 43 orang untuk balita bukan pneumonia sehingga jumlah sampel seluruhnya sebanyak 86 orang.

Terhadap semua para orangtua dari subjek diberikan penjelasan mengenai penelitian dan 
menandatangani persetujuan anaknya ikut dalam penelitian (informed consent). Seluruh data demografis, faktor risiko, dan karakteristik gejala klinis yang relevan dengan penelitian ini dicatat di dalam formulir penelitian ini. Data itu termasuk usia, jenis kelamin, riwayat berat badan lahir, riwayat pemberian ASI eksklusif, riwayat imunisasi, gejala klinis berupa lama hari demam, lama hari batuk, laju napas, dan sesak napas. Berat badan ditimbang mempergunakan alat electronic scale untuk anak usia 6-24 bulan dan dengan timbangan berdiri untuk anak usia 25-59 bulan. Panjang dan tinggi badan diukur dengan infantometer dan microtoise. Status gizi ditentukan mempergunakan baku antropometri dari WHO Child Growth Standard atau WCGS. Pemeriksaan penunjang berupa tes laboratorium darah dan foto rontgen dada.

Analisis statistik penelitian ini menggunakan program dari statistical package for the social science (SPSS) versi 17. Data proporsi disajikan dalam frekuensi dan persentase, sedangkan data numeriknya disajikan dalam rata-rata. Hubungan antara kelompok subjek dan kejadian pneumonia dianalisis memakai uji chi-kuadrat, uji eksak Fisher, Kolmogorov-Smirnov, dan Spearman.

\section{Hasil}

Berdasarkan tabel terdapat 86 balita dengan diagnosis pneumonia dan bukan pneumonia, sebagian besar subjek balita berada pada rentang usia 6-24 bulan dan didominasi oleh laki-laki. Status gizi berdasarkan $\mathrm{BB} / \mathrm{U}$ paling banyak anak balita dengan status gizi baik sebanyak 56 orang dan terdapat perbedaan bermakna antara pneumonia dan bukan pneumonia $(\mathrm{p}<0,001)$. Berdasarkan TB/U dan juga BB/TB paling banyak adalah anak balita dengan status gizi normal. Sebagian besar subjek penelitian memiliki berat lahir $\geq 2.500$ g (tidak BBLR) sebanyak 81 orang (94\%) memiliki riwayat diberikan ASI eksklusif sebanyak 79 orang (92\%), dan didominasi oleh anak balita yang telah mengikuti imunisasi dasar lengkap sebanyak 80 orang (93\%), tetapi tidak berbeda bermakna antara pneumonia dan bukan pneumonia.

Anak balita dengan pneumonia sebagian besar berusia 6-24 bulan (72\%), laki-laki (63\%), berstatus gizi kurang berdasarkan $\mathrm{BB} / \mathrm{U}$ (56\%), memiliki berat badan lahir $\geq 2.500$ gram (95\%), riwayat diberikan ASI eksklusif (91\%), dan telah mendapatkan imunisasi dasar lengkap (93\%).
Berdasarkan atas gejala klinis, balita dengan pneumonia mengalami lama hari demam dan batuk rata-rata yang lebih lama, serta takipnea dengan laju napas rata-rata lebih cepat dibanding dengan balita bukan pneumonia. Berdasarkan atas klasifikasi pneumonia, sebanyak 4 orang (9\%) dari anak balita yang telah didiagnosis pneumonia mengalami pneumonia berat yang semuanya berada di dalam rentang usia 6-24 bulan, sebanyak 3 orang laki-laki dan berstatus gizi kurang berdasarkan atas BB/U. Gejala klinis, yaitu lama demam, lama batuk, dan juga takipnea berbeda bermakna antara pneumonia dan bukan pneumonia $(\mathrm{p}=0,024 ; \mathrm{p}=0,048$; dan $\mathrm{p}<0,001)$.

\section{Pembahasan}

Berdasarkan atas hasil penelitian pada anak balita pneumonia didapatkan bahwa sebagian besar anakbalitaberusiaberkisar6-24bulan. Penelitian terdahulu di RS Adam Malik Medan selama 3 (tiga) tahun melakukan penelitian mendapatkan hasil bahwa usia 3-23 bulan merupakan usia paling sering terjadi pneumonia. ${ }^{10}$ Penelitian lain di RS dr. Sardjito Yogyakarta tahun 2007 mendapatkan bahwa usia penderita pneumonia anak rata-rata 16,1 bulan dan $52 \%$ berusia $<1$ tahun. Hal ini dijelaskan bahwa anak di bawah usia 1 tahun memiliki saluran napas yang lebih sempit sehingga akan mudah menderita infeksi saluran pernapasan seperti pneumonia dan bila area yang terkena peradangan bertambah luas akan menyebabkakan risiko terjadinya obstruksi saluran pernapasan dan meningkatkan kejadian hipoksia. ${ }^{11}$ Penelitian dinegaraZambia dinyatakan bahwa pneumonia merupakan penyebab utama kesakitan pada anak di bawah usia 5 tahun, ${ }^{12}$ hal ini dapat terjadi karena pada usia tersebut anak balita sudah mulai mengetahui lingkungan untuk bermain di luar rumah sehingga akan mudah terpapar oleh agen penyebab pneumonia dan didukung oleh respons imunitas yang belum berkembang dengan baik. ${ }^{5}$

Jenis kelamin anak balita yang datang untuk berobat ke UPT Puskesmas Ibrahim Aji didominasi oleh balita laki-laki sebanyak 59\% bila dibandingkan dengan perempuan sebanyak 41\%. Jenis kelamin laki-laki tersebut sesuai dengan hasil beberapa penelitian sebelumnya yang menyatakan bahwa balita laki-laki lebih sering terkena pneumonia dibanding dengan perempuan., ${ }^{213-15}$ Balita laki-laki berisiko 1,5 kali menderita pneumonia bila dibandingkan dengan 
Tabel 1 Karakteristik Subjek berdasarkan Demografis, Faktor Risiko, Gejala Klinis, dan Hubungannya dengan Kejadian Pneumonia

\begin{tabular}{|c|c|c|c|c|c|c|c|c|}
\hline \multirow{2}{*}{$\begin{array}{l}\text { Karakteristik } \\
\text { Subjek }\end{array}$} & \multicolumn{4}{|c|}{ Pneumonia } & \multicolumn{2}{|c|}{ Bukan Pneumonia } & \multirow{2}{*}{$\begin{array}{c}\text { Nilai } \\
\text { p }\end{array}$} & \multirow{2}{*}{$\begin{array}{c}\text { Nilai } \\
\mathbf{r}\end{array}$} \\
\hline & n (\%) & $\begin{array}{c}\text { Rata-rata } \\
\text { (SB) }\end{array}$ & $\begin{array}{c}\text { Median } \\
\text { (rentang) }\end{array}$ & n (\%) & $\begin{array}{l}\text { Rata-rata } \\
\text { (SB) }\end{array}$ & $\begin{array}{l}\text { Median } \\
\text { (rentang) }\end{array}$ & & \\
\hline Usia (bulan) & & $20(14,2)$ & $53(6-59)$ & & $25(15,5)$ & $49(6-55)$ & & \\
\hline $6-24$ & $31(72)$ & & & $24(56)$ & & & $0,245^{*}$ & \\
\hline $25-59$ & $12(28)$ & & & $19(44)$ & & & & \\
\hline Jenis kelamin & & & & & & & $0,510^{*}$ & \\
\hline Laki-laki & $27(63)$ & & & $24(56)$ & & & & \\
\hline Perempuan & $16(37)$ & & & $19(44)$ & & & & \\
\hline \multicolumn{9}{|l|}{$\begin{array}{l}\text { Status gizi } \\
\text { berdasarkan }\end{array}$} \\
\hline $\mathbf{B B} / \mathbf{U}$ & & & & & & & $<0,001^{* * *}$ & $-0,7$ \\
\hline Baik & $15(35)$ & & & $41(95)$ & & & & \\
\hline Kurang & $24(56)$ & & & $\mathrm{o}(\mathrm{o})$ & & & & \\
\hline Buruk & $4(9)$ & & & o (o) & & & & \\
\hline Lebih & o (o) & & & $2(5)$ & & & & \\
\hline \multicolumn{9}{|l|}{ Berdasarkan } \\
\hline $\mathbf{T B} / \mathbf{U}$ & & & & & & & $1,000^{*}$ & \\
\hline Tinggi & $3(7)$ & & & $2(5)$ & & & & \\
\hline Normal & $23(54)$ & & & $30(70)$ & & & & \\
\hline Pendek & $10(23)$ & & & $8(18)$ & & & & \\
\hline $\begin{array}{l}\text { Sangat } \\
\text { pendek }\end{array}$ & $7(16)$ & & & $3(7)$ & & & & \\
\hline \multicolumn{9}{|l|}{ Berdasarkan } \\
\hline BB/TB & & & & & & & $0,110^{* * *}$ & \\
\hline Normal & $28(65)$ & & & $37(86)$ & & & & \\
\hline Kurus & $11(26)$ & & & $3(7)$ & & & & \\
\hline Sangat kurus & $4(9)$ & & & $\mathrm{o}(0)$ & & & & \\
\hline Gemuk & o (o) & & & $3(7)$ & & & & \\
\hline \multicolumn{9}{|l|}{ BBLR } \\
\hline Ya & $2(5)$ & & & $3(7)$ & & & $0,500^{* * *}$ & \\
\hline Tidak & $41(95)$ & & & $40(93)$ & & & & \\
\hline \multicolumn{9}{|l|}{ Riwayat ASI } \\
\hline $\mathrm{Ya}$ & $39(91)$ & & & $40(93)$ & & & $0,513^{* *}$ & \\
\hline Tidak & $4(9)$ & & & $3(7)$ & & & & \\
\hline \multicolumn{9}{|l|}{ Imunisasi dasar } \\
\hline \multicolumn{9}{|l|}{ lengkap } \\
\hline $\mathrm{Ya}$ & $40(93)$ & & & $40(93)$ & & & $0,662^{* *}$ & \\
\hline Tidak & $3(7)$ & & & $3(7)$ & & & & \\
\hline \multicolumn{9}{|l|}{$\begin{array}{l}\text { Karakteristik } \\
\text { gejala klinis }\end{array}$} \\
\hline $\begin{array}{l}\text { Lama demam } \\
\text { (hari) }\end{array}$ & & $3(1,3)$ & $6(1-7)$ & & $2(1,0)$ & $4(1-5)$ & $0,024^{* * * *}$ & -0.2 \\
\hline $\begin{array}{l}\text { Lama batuk } \\
\text { (hari) }\end{array}$ & & $4(2,3)$ & $13(1-14)$ & & $3(2,1)$ & $6(1-7)$ & $0,048^{* * * *}$ & $-0,2$ \\
\hline $\begin{array}{l}\text { Takipnea } \\
\text { (kali/menit) }\end{array}$ & & $51(8,5)$ & $40(40-80)$ & & $34(4,8)$ & $18(26-44)$ & $<0,001^{* * * *}$ & $-0,8$ \\
\hline
\end{tabular}


perempuan, hal ini dimungkinkan oleh diameter jalan napas pada anak balita laki-laki lebih kecil dibanding dengan perempuan atau perbedaan dalam ketahanan tubuh yang dipengaruhi oleh kromosom seks. ${ }^{16}$

Status gizi merupakan salah satu unsur yang penting yang turut menentukan risiko seorang balita rentan terkena suatu penyakit. Berdasarkan atas BB/U didapatkan sebagian besar anak balita pneumonia dengan status gizi kurang dibanding dengan balita bukan pneumonia dengan status gizi yang normal, dan berdasarkan statistik terdapat hubungan yang kuat antara status gizi dan kejadian pneumonia. Semakin kurang status gizi balita semakin tinggi terjadi pneumonia. Hal ini sesuai dengan penelitian di Brazil yang menyatakan bahwa variabel antropometri $\mathrm{BB} / \mathrm{U}$ berhubungan dengan risiko terjadi pneumonia, yaitu balita dengan gangguan gizi 5 kali lebih berisiko untuk mengalami kejadian pneumonia. ${ }^{13}$ Penyakit pneumonia itu lebih banyak didapatkan pada anak-anak balita dengan gangguan gizi..$^{14,16}$ Parameter BB/U termasuk indikator yang baik untuk mengukur status gizi seseorang saat ini. ${ }^{17}$ Bayi berat lahir rendah atau BBLR merupakan salah satu faktor risiko untuk pneumonia. ${ }^{1}$ Bayi berat lahir rendah dapat memengaruhi penyakit pneumonia melalui penurunan respons imun dan kegagalan fungsi paru-paru pada bayi tersebut. ${ }^{13}$

Imunisasi merupakan salah satu strategi spesifik yang ternyata dapat mengurangi angka kematian karena pneumonia. ${ }^{18}$ Berdasarkan atas penelitian didapatkan bahwa pada BBLR dan imunisasi dasar lengkap antara balita dengan pneumonia dan bukan pneumonia tidak berbeda bermakna, sebagian besar bukan BBLR dan telah mendapat imunisasi dasar yang lengkap, tetapi tidak ditanyakan atau dicatat jenis imunisasi apa yang telah diberikan yang sesuai dengan usia. Hal ini sesuai dengan penelitian sebelumnya yang menyatakan bahwa BBLR dan imunisasi tidak lengkap walaupun memiliki nilai OR yang besar sebagai faktor risiko, tetapi belum dapat disimpulkan sebagai faktor risiko. ${ }^{19}$ Bayi yang diberi ASI eksklusif ternyata dapat mengurangi risiko pneumonia. ${ }^{20}$ Kandungan ASI eksklusif memiliki anti-infektif untuk perlindungan pasif melawan patogen dan menstimulus sistem imun bayi. ${ }^{13}$ Subjek pada penelitian ini sebagian besar memiliki riwayat telah diberikan ASI eksklusif, hal ini sesuai dengan penelitian sebelumnya di RS dr. Kariadi Semarang yang menyatakan bahwa anak yang mendapat ASI eksklusif mempunyai kemungkinan menderita infeksi respiratori akut (IRA) bawah lebih rendah o,5 kali bila dibanding dengan anak-anak tanpa riwayat ASI eksklusif, namun belum dapat disimpulkan sebagai faktor protektif. ${ }^{19}$

Menurut kriteria WHO manifestasi klinis pneumonia itu adalah batuk, demam, takipnea (terdapat peningkatan laju pernapasan), napas cuping hidung, dan hipoksia yang ditunjang dengan pemeriksaan foto rontgen dada. ${ }^{21}$ Hasil penelitian ini menunjukkan lama hari demam rata-rata lebih lama pada anak balita pneumonia bilamana dibanding dengan bukan pneumonia (3 hari vs 2 hari), hal tersebut sesuai dengan hasil penelitian di Boston (USA) bahwa durasi demam pada pneumonia sebagian besar adalah $\leq 72$ jam $(58,2 \%){ }^{22}$ Berdasarkan penelitian sebelumnya terdapat hari demam rata-rata yang ternyata lebih lama pada pneumonia dengan komplikasi bila dibanding dengan tanpa komplikasi karena luasnya parenkim paru yang terkena. ${ }^{23}$

Terdapat hari batuk rata-rata yang lebih lama pada balita pneumonia apabila dibanding dengan balita bukan pneumonia. Penelitian di Aceh menunjukkan bahwa batuk merupakan manifestasi klinis yang paling banyak dijumpai ${ }^{24}$ dan di Irak batuk juga merupakan gejala yang paling banyak dijumpai pada pneumonia. ${ }^{15}$ Penelitian di Boston (USA) mendapatkan bahwa durasi batuk pada pneumonia sebagian besar $\leq 72$ jam (52,9\%). ${ }^{22}$ Hasil penelitian didapatkan bahwa laju pernapasan rata-rata lebih tinggi/takipnea pada balita pneumonia dibanding dengan bukan pneumonia.

Takipnea merupakan salah satu gejala klinis yang penting dalam menegakkan diagnosis pneumonia. Penelitian yang sudah dilakukan menyatakan bahwa takipnea pada pneumonia mempunyai nilai sensitivitas sebesar $74 \%$ dan spesifisitas sebesar $67 \% .{ }^{24}$ Berdasarkan hasil penelitian terdapat hubungan lama demam, lama batuk, dan takipnea dengan kejadian pneumonia. Penelitian di Dallas Amerika Serikat mendapatkan gejala klinis yang lebih singkat pada pneumonia yang disebabkan oleh $M$. pneumoniae dan campuran bakteri atau virus dibanding dengan oleh tipikal bakteri (3,5-5 hari vs 6 hari). ${ }^{25}$ Pneumonia oleh bakteri biasanya menyebabkan anak sakit berat secara mendadak. ${ }^{8}$

Anak-anak yang berusia 2 tahun ke atas mempunyai etiologi infeksi bakteri lebih banyak dibanding dengan anak berusia di bawah 2 tahun, tetapi secara klinis umumnya pneumonia karena bakteri sulit dibedakan dengan pneumonia virus. ${ }^{1}$ 
Penelitian ini tidak dapat menentukan jenis kuman penyebab pneumonia disebabkan oleh keterbatasan pada pemeriksaan laboratorium. Faktor usia memegang peranan penting pada perbedaan dan juga kekhasan pneumonia anak, terutama dalam hal spektrum etiologi, gambaran klinis, dan strategi pengobatan. ${ }^{1}$ Klinisi harus tetap berhati-hati dalam menilai takipnea pada anak pneumonia yang terjadi lebih awal, yaitu pada anak dengan gejala klinis yang terjadi kurang dari 3 (tiga) hari. ${ }^{26}$ Takipnea mempunyai nilai sensitivitas dan juga spesifisitas yang rendah sehingga klinisi harus lebih waspada bila tidak mendapatkan takipnea dari pemeriksaan fisis bukan berarti tidak menderita pneumonia. ${ }^{27}$

\section{Simpulan}

Terdapat hubungan yang kuat antara status gizi anak dan kejadian pneumonia. Terdapat pula hubungan lama demam, lama batuk, dan takipnea dengan kejadian pneumonia balita.

\section{Ucapan Terima Kasih}

Ucapan terima kasih kepada Prof. Dr. Ieva B. Akbar, dr., AIF selaku Dekan Fakultas Kedokteran Universitas Islam Bandung dan semua pihak yang telah membantu penelitian ini.

\section{Daftar Pustaka}

1. Said M. Pneumonia. Dalam: Rahajoe NN, Supriyanto B, Setyanto DB, penyunting. Buku ajar respirologi anak. Edisi pertama. Jakarta: Sagung Seto; 2008. hlm. 350-64.

2. Anggrek K, Runtunuwu AL, Wahani A, Margaretha L. Faktor risiko kejadian distres pernapasan pada anak dengan pneumonia. Sari Pediatri. 2008;9:391-7.

3. World Health Organization, UNICEF. Global action plan for prevention and control of pneumonia (GAPP). Geneva: WHO; 2009.

4. Said M. Pengendalian pneumonia anakbalita dalam rangka pencapaian MDG4. Bul Jendela Epidemiol. 2010;3:16-21.

5. United Nations Children's Fund (UNICEF) and World Health Organization. Pneumonia the forgotten killer of children. New York: UNICEF; 2006.

6. Departemen Kesehatan RI. Profil Kesehatan Indonesia Tahun 2013. Jakarta: Departemen Kesehatan RI; 2013.
7. Departemen Kesehatan RI. Profil Kesehatan Indonesia Tahun 2008. Jakarta: Departemen Kesehatan RI; 2009.

8. Kartasasmita BC. Pneumonia pembunuh balita. Bul Jendela Epidemiol. 2010;3:22-6.

9. Departemen Kesehatan RI. Manajemen terpadu balita sakit (MTBS). Modul 1-7. Edisi ke-2. Jakarta: Dirjen Kesehatan RI; 2005.

10. Dalimunthe W, Daulay SR, Daulay MR. Significant clinical features in pediatric pneumonia. Paediatr Indones. 2013;53:3741.

11. Kisworini P, Setyani A, Sutaryo. Mortality predictors of pneumonia in children. Paediatr Indones. 2010;50:149-53.

12. Stekelenburg J, Kasumba E, Wolffers I. Factor contributing to high mortality due to pneumonia among under-fives in Kalabo districs, Zambia. TMIH. 2002 Oktober;7(Issue 10):886-93.

13. Victoria CG, Fuchs SC, Flores JA, Fonseca W. Risk factors for pneumonia among children in a Brazilian metropolitan area. AAP. 1994;93:1-10.

14. Subanada IB, Purniti NPS. Faktor-faktor yang berhubungan dengan pneumonia bakteri pada anak. Sari Pediatri. 2010;12(3):184-9.

15. Al-Ghizawi GJ, Al-Sulami AA, Al-Taher SS. Profile of community-and hospital-acquired pneumonia cases admitted to Basra General Hospital, Iraq. Easern Mediterranean Health J. 2007;13:230-42.

16. Sunyataningkamto, Iskandar Z, Alan RT, Budiman I, Surjono A. The role of indoor air pollution and other factors in the incidence of pneumonia in under-five children. Paediatr Indones. 2004;44:25-9.

17. Supariasa IDN, Bachyar B, Ibnu F, penyunting. Penilaian status gizi. Jakarta: EGC; 2001.

18. Graham NMH. The epidemiology of acute respiratory disease in children and adult: a global prespective. Epidemiol Rev. 2005:149-78.

19. Tamba R, Sidhartani M, Musrichan. Faktor risiko infeksi respiratorik akut bawah pada anak. Sari Pediatri. 2010;11:330-4.

20. Cahntry CJ, Howard CR, Auinger P. Full breastfeeding duration and associated decrease in respiratory tract infection in US children. Pediatrics. 2006;117:425-32.

21. Tiewosh K, Lodha R, Pandey RM, Broor S, 
Kalaivani M, Kabra SK. Factors determining the outcome of children hospitalized with severe pneumonia. BMC Pediatr. 2009;9:18.

22. Neuman MI, Monuteaux MC, Scully KJ, Bachur RG. Prediction of pneumonia in a pediatric emergency department. Pediatrics. 2011 August;128(Issue 2):246-53.

23. Tan TQ, Mason EO, Wald ER, Barson WJ, Schutze GE, Bradley JS, dkk. Clinical characteristic of children with complicated pneumonia caused by Streptococcus pneumoniae. Pediatrics. 2002 July;110(Issue 1):1-6.

24. Nurjannah, Sovira N, Anwar S. Profil pneumonia pada anak di RSUD dr. Zainoel
Abidin, studi retrospektif. Sari Pediatri. 2012;5:324-7.

25. Michelow IC, Olsen K, Lazano J, Rollins NK, Duffy LB, Ziegler T, dkk. Epidemiology and clinical characteristic of communityaquired pneumonia in hospitalized children. Pediatrics. 2004 April;113(Issue 4):701-7.

26. Palavox M, Guiscafre H, Reyes H, Munoz O, Martinez H. Diagnostic value of tachypnoea in pneumonia define radiologically. Arch Dis Child. 2000;82:41-5.

27. Lakhanpaul M, Atkinson M, Stephenson T. Community acquired pneumonia in children: a clinical update. Arch Dis Child Educ Pract. 2004;89:29-34. 